\title{
Food limitation and the recovery of sea otters following the 'Exxon Valdez' oil spill
}

\author{
Thomas A. Dean ${ }^{1, *}$, James L. Bodkin ${ }^{2}$, Allan K. Fukuyama ${ }^{3}$, Stephen C. Jewett ${ }^{4}$, \\ Daniel H. Monson ${ }^{2}$, Charles E. O'Clair ${ }^{5}$, Glenn R. VanBlaricom ${ }^{3}$ \\ ${ }^{1}$ Coastal Resources Associates, 5674 El Camino Real, Suite M, Carlsbad, California 92008, USA \\ ${ }^{2}$ Biological Resources Division, US Geological Survey, Alaska Biological Science Center, 1011 East Tudor Road, Anchorage, \\ Alaska 99503, USA \\ ${ }^{3}$ Washington Cooperative Fish and Wildlife Research Unit, Biological Resources Division, US Geological Survey, \\ School of Aquatic and Fishery Sciences, PO Box 355020, University of Washington, Seattle, Washington 98195-5020, USA \\ ${ }^{4}$ Institute of Marine Science, University of Alaska Fairbanks, Fairbanks, Alaska 99775-7220, USA \\ ${ }^{5}$ National Marine Fisheries Service, Auke Bay Laboratory, 11305 Glacier Highway, Juneau, Alaska 99801, USA
}

\begin{abstract}
We examined the potential role of food limitation in constraining the recovery of sea otters Enhydra lutris in Prince William Sound, Alaska, following the 'Exxon Valdez' oil spill. The spill resulted in the removal of a large number of sea otters in 1989, and as of 1998, the portion of the population in the heavily oiled northern Knight Island region had not fully recovered. Between 1996 and 1998, prey consumption rate was higher and the condition of sea otters was better at northern Knight Island than in an unoiled area of the sound (Montague Island). Estimates of prey energy available per unit mass of sea otter were about 4 times higher at Knight than Montague Island, albeit not significantly different between the 2 areas. Over this same period, the number of sea otters remained constant at northern Knight Island but increased at Montague Island. These data suggest that food was at least as abundant at Knight than at Montague Island, and that recovery of sea otters via intrinsic population growth was limited by factors other than food. However, the availability of food, the prey consumption rate, and the condition of sea otters were all much lower at both Knight and Montague Islands than in areas newly occupied by sea otters where the population growth rate was near the theoretical maximum. It is possible that the relatively short supply of food (compared to areas where sea otter population growth rate was high) may have inhibited immigration or interacted with other factors (e.g. oil-induced mortality or predation) to restrict sea otter population growth. Nonetheless, these data suggest that impacts of anthropogenic disturbances on large, often food-limited vertebrate predators can persist in spite of the availability of food resources that are sufficient for intrinsic population growth.
\end{abstract}

KEY WORDS: Prince William Sound - Alaska - Predator-prey interaction - Prey availability · Prey consumption rate $\cdot$ Condition indices

\section{INTRODUCTION}

The 'Exxon Valdez' ran aground in Prince William Sound (PWS), Alaska, in March 1989, and the estimated 42 million liters of crude oil that were spilled from the tanker had severe adverse impacts on the

*E-mail: coastal_resources@sbcglobal.net nearshore ecosystem (Paine et al. 1996, Spies et al. 1996, Peterson 2001). One effect of the spill was the removal (either via death or for the purposes of rehabilitation and permanent placement in captivity) of a significant proportion of the sea-otter Enhydra lutris population in heavily oiled parts of PWS (Garrott et al. 1993, Bodkin \& Udevitz 1994, Garshelis 1997, Dean et al. 2000). An estimated 165 sea otters were removed from the heavily oiled area of the western sound 
around northern Knight Island as a result of the spill (Dean et al. 2000), and few if any sea otters remained there following the spill in summer 1989 (Bodkin \& Udevitz 1994, J. L. Bodkin \& D. H. Monson unpubl. data). As of 1998, the sea otter population in this area had not fully recovered (Dean et al. 2000, Bodkin et al. 2002, this issue). From 1993 to 1998, yearly aerial surveys at northern Knight Island found fewer than 90 sea otters, and there was no significant increase in sea otter density over this period. In 1997 and 1998, there were an estimated 76 sea otters, far fewer than the 237 sea otters found in a pre-spill census of the area in 1973, and fewer than half the number of sea otters removed in 1989 following the spill. In contrast, along Montague Island, an area within PWS unaffected by the spill, sea otter density increased between 1993 and 1998, and was 27\% higher in 1998 than in 1973.

Models using age-distribution of carcasses collected from beaches indicate that survival of sea otters in oiled areas was lower after the spill than before (Monson et al. 2000a). However, the causes for poorer survival and lack of recovery of sea otters in the northern Knight Island region have not been identified. Determining these causes is important in managing and conserving sea otter populations, evaluating the overall health of the nearshore system during recovery following the oil spill, and predicting patterns and rates of recovery following environmental perturbations of similar scope and type (Bodkin et al. 2002). We hypothesize that the lack of recovery was the result of: (1) a slow rate of increase in sea otter populations, even in the absence of chronic effects of the spill, (2) continued exposure to oil and concomitant effects on survival, immigration, or emigration rates, or (3) a lack of food (resulting from reductions in prey abundance caused by the spill or from natural causes). In this paper, we examine the evidence regarding the food limitation hypothesis by comparing the prey availability, prey consumption rate, and condition of sea otters in an oiled vs unoiled area in PWS.

The diet of sea otters in PWS consists mostly of clams, primarily Saxidomus gigantea, Protothaca staminea, Humilaria kennerleyi, Macoma spp., and Mya spp. (Calkins 1978, Estes et al. 1981, Garshelis et al. 1986, Doroff \& Bodkin 1994). Crabs, primarily Telmessus cheiragonus, and mussels Mytilus trossulus are taken somewhat less frequently, although mussels may be an important food resource for juvenile sea otters (VanBlaricom 1988). Occasional prey in PWS include echiurid and polychaete worms, sea urchins, and sea stars. Densities of some sea-otter prey were reduced at sites adjacent to heavily oiled beaches in PWS following the oil spill in 1989. These included M. trossulus (Gilfillan et al. 1995, Highsmith et al. 1996, Houghton et al. 1996), P. staminea (Driskell et al. 1996, Trow- bridge et al. 1998, Fukuyama et al. 2000), and $T$. cheiragonus (Dean et al. 1996). The recovery status of these populations has not been fully evaluated. There is some evidence that communities in the rocky intertidal and rocky subtidal habitats had recovered by 1992 or 1993, 3 to 4 yr after the spill (Coats et al. 1999, Dean \& Jewett 2001). However, for P. staminea, mortality rates were higher and growth was slower in oiled areas through 1996 (Fukuyama et al. 2000) and adverse impacts of the oil spill to some species of infauna in subtidal, soft-sediment eelgrass habitats persisted through 1995, and perhaps longer (Jewett et al. 1999, Dean \& Jewett 2001).

In the 2 decades prior to the oil spill, sea otter densities in our oiled (northern Knight Island) and reference (Montague Island) study areas were relatively stable (reviewed in Bodkin et al. 2000) and further population growth was considered to be limited by food (Garshelis et al. 1986, VanBlaricom 1988). This was based on observations of a relative reduction in several key food items (crabs and mussels) coincident with sea otter expansion and on sea otter feeding observations (Estes et al. 1981, Garshelis et al. 1986). In the early 1980s, sea otters from (or near) our study areas spent approximately twice as long foraging than otters in parts of PWS where the population had only recently expanded (Estes et al. 1981, Garshelis et al. 1986). The fact that the pre-spill population of sea otters was apparently food-limited, coupled with evidence of reductions in sea-otter prey as a result of the spill, suggested that food may be limiting recovery of sea otters.

Over the course of our study (from 1996 through 1998) there was an increase in sea otter density in unoiled portions of western PWS, but no increase in the heavily oiled region around northern Knight Island (Dean et al. 2000). Therefore, demonstration of less food in the oiled area would suggest that food was limiting recovery there. On the other hand, equal or greater abundance of food at the oiled site would indicate that factors other than food were responsible. We relied on both direct and indirect measures of food availability because it is difficult to measure precisely the abundance of the diverse group of sea otter prey, and because prey abundance does not account for factors such as quality of food or the cost to the predator of acquiring its prey. In the absence of other factors that can influence prey abundance, a reduction in the density of food-limited mammalian predators generally leads to an increase in either quantity or quality of food available, and an increase in the condition of the remaining (especially younger) animals (Bobek 1977, Sinclair 1977, Skogland 1983, 1985, Bayliss 1985, Sinclair et al. 1985, Fryxell 1987, Freeland \& Choquenot 1990, Choquenot 1991, Messier 1994). Therefore, in addition to prey abundance, we examined prey con- 
sumption rate and condition of young sea otters as further indicators of food limitation. Prey consumption rate and condition of animals are often better indictors of food resources than direct measures of prey abundance, especially for large marine mammals (Eberhardt \& Siniff 1977).

\section{MATERIALS AND METHODS}

Design. As is the case for most large motile predators, it is not practical to test experimentally the food limitation hypothesis (Estes 1996). Instead, we will rely on 3 separate lines of indirect evidence concerning: (1) the availability of food, in terms of both prey energy per unit area and prey energy per unit mass of sea otter, (2) the rate of consumption of food by sea otters, and (3) morphometric characteristics (age-adjusted mass and mass to length ratio) for sea otters that might be expected to be affected by the availability of food. Evaluation of these 3 relatively independent data sets (prey availability, prey consumption rate, and condition of sea otters) provides a more rigorous test of the food limitation hypothesis than evaluation based on any single line of evidence.

For all 3 factors, we compare a heavily oiled area in the vicinity of northern Knight Island with an unoiled area at Montague Island. The Montague site was relatively unaffected by the spill (ADEC 1989, ADNR 1991, Galt et al. 1991, Wolfe et al. 1994, O'Clair et al. 1996, Jewett et al. 1999) and there were no detectable impacts to sea otters (Ballachey et al. 1994) or nearshore benthic communities (Dean et al. 1996, Jewett et al. 1999). Based on the history of sea otter recolonization in PWS following their near extinction in the late 1900s, observations of sea-otter movements, and phenotypic and genotypic characteristics of individuals from throughout PWS, it is clear that sea otters at Knight and Montague Islands are subsets of a larger metapopulation (Gorbics \& Bodkin 2001). However, mark-recapture studies indicated little if any movement of sea otters between our Knight and Montague study areas between 1996 and 1999 (Bodkin et al. 2002). Between 1996 and 1998, a total of 66 and 91 sea otters were tagged at northern Knight and Montague Island respectively, and a total of 47 tagged sea otters were observed between 1997 and 1999 in each area. None of the sea otters tagged at Knight Island were observed at Montague Island or vice versa. Population densities of sea otters were likely lower at northern Knight Island than at Montague Island at the time of the spill in 1989 (Dean et al. 2000), but sea otters in both areas were considered food-limited and at or near equilibrium prior to the spill (Estes et al. 1981, Garshelis et al. 1986, Bodkin et al. 2002).
For each metric (prey energy per unit area, prey energy per unit mass of sea otter, consumption rate of prey, age-adjusted mass, and mass to length ratio), we tested the hypothesis that there was no difference at northern Knight Island vs Montague Island against the alternative hypothesis that values for these metrics were greater at Knight Island. Equal or higher values at Knight Island would indicate that recovery of sea otters at Knight Island was limited by factors other than food.

When possible, we also compared post-spill values for each metric for the northern Knight and Montague Island with pre-spill PWS values, and with similar data for sea otter populations outside of PWS. Histories of sea otter colonization in these areas are known, and the status of the populations with respect to food limitation is generally acknowledged (Lensink 1962, Kenyon 1969, Estes et al. 1986, Garshelis et al. 1986, Kvitek et al. 1992).

We recognize that this is a pseudoreplicated design in that we primarily rely on comparisons between a single oiled area with a single unoiled reference area (Hurlbert 1984, Stewart-Oaten et al. 1986). Therefore, statistical inference can be made only to those 2 areas and not to other areas within PWS that were impacted by the spill, to spill-impacted areas outside of the sound, or to other oil spills. However, our northern Knight Island study area represents one of the most heavily oiled parts of the sound where sea otters were not recovering, and we were primarily interested in evaluating why recovery of sea otters in this particular area was slow. We did not replicate reference areas (e.g. other unoiled parts of PWS) primarily because of cost constraints. However, the increase in sea otters that we observed in our Montague study area over the course of the study was also observed in other unoiled portions of PWS (Bodkin et al. 2002). Thus, patterns observed at Montague are reflective of sound-wide patterns, at least with respect to this 1 important aspect. We also recognize that our design relies largely on post-spill comparisons (especially with respect to food availability) and that interpretations of results with respect to potential food limitation rest on assumptions regarding food resources and the status of food limitation in sea-otter populations prior to the spill. However, based on the long history of sea-otter occupation in our study areas (Lensink 1962), and the widely recognized impact of sea otters on their food resources (e.g. Kvitek et al. 1992, Estes \& Duggins 1995), the assumption that sea otters in both our study areas were food-limited prior to the spill seems reasonable.

Food availability. We used 2 metrics to assess prey availability because of uncertainties as to how sea otters perceive their prey base, uncertainties as to 


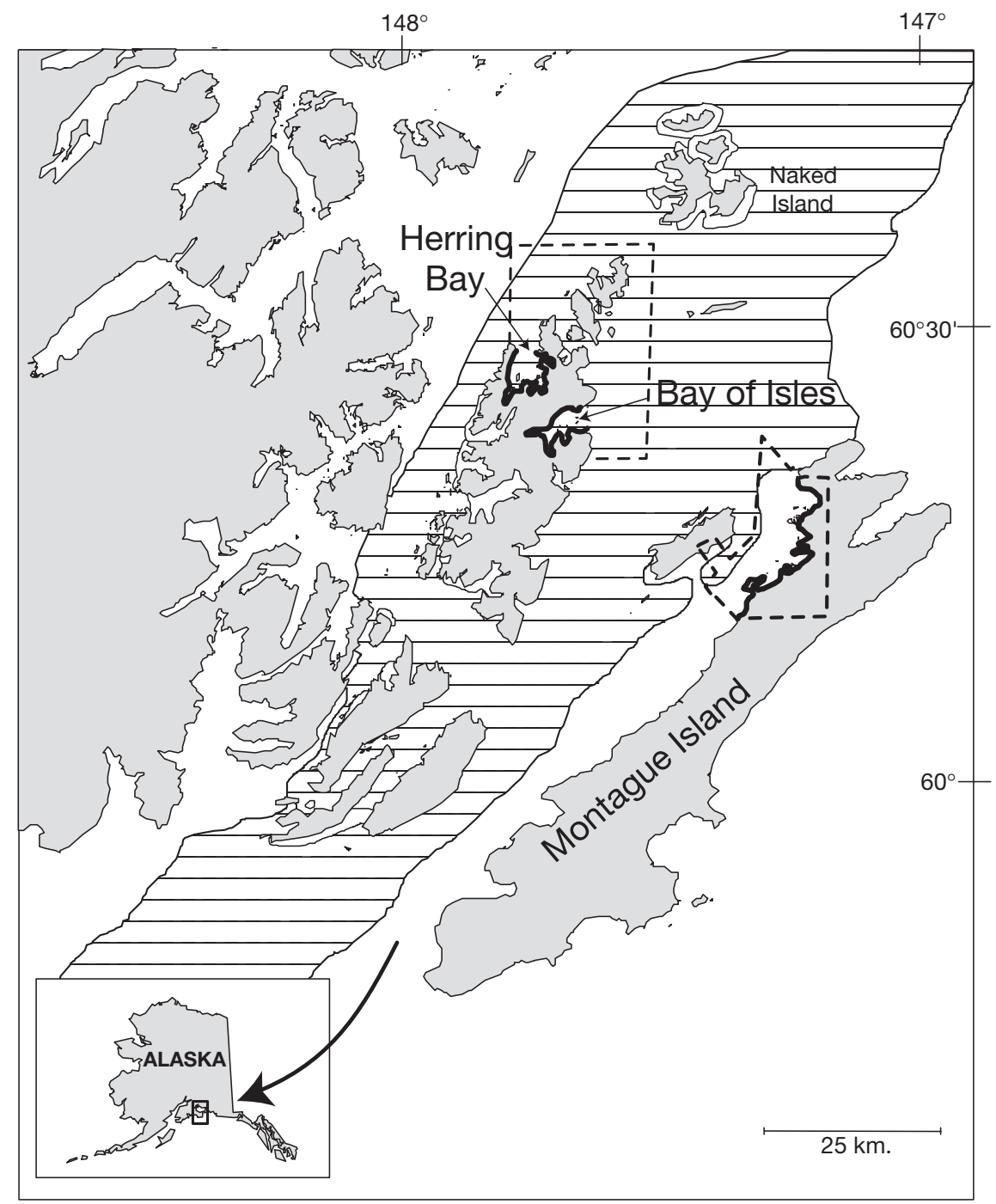

Fig. 1. Location of sampling sites for sea otters and sea otter prey in western Prince William Sound. The cross-hatched area indicates the trajectory of oil from the 'Exxon Valdez' oil spill based on a hind-cast model (Galt et al. 1991) and shoreline oiling surveys (ADEC 1989, ADNR 1991). Areas where sea otters were surveyed are indicated by dotted lines. Thickened lines indicate shoreline areas in Herring Bay and Bay of Isles on Knight Island and Montague Island, where prey were sampled in 1996 through 1998

whether recovery of sea-otter populations may be dependent on immigration or intrinsic growth (i.e. growth resulting from births in the resident population), and known differences between our 2 study areas. First, we examined the energy of prey available per unit area. We assume that immigrating sea otters might assess the suitability of a particular habitat based on the prey that can be obtained in a few foraging sessions, and that the average prey density (i.e. mean prey energy per unit area) is a reasonable index of what an immigrating sea otter might encounter. This especially may be the case for young sea otters that have little knowledge of preferred feeding sites, where prey densities may be higher than average. Younger sea otters (especially young males) are the most likely immigrants (Reidman \& Estes 1990).
However, energy available per unit area might not be a reasonable means of assessing the status of a particular area with respect to its carrying capacity and its potential with respect to intrinsic population growth. Our Montague Island study area supported higher densities of sea otters than our northern Knight Island study area prior to the spill, and there are known differences between the 2 study areas that suggest that Montague Island might support a more productive prey base. In a pre-spill census conducted in 1973, densities of sea otters were 5.4 and $1.4 \mathrm{~km}^{-2}$ at Montague and Knight Island study areas respectively (Dean et al. 2000). The Montague study area is generally shallower and has a higher proportion of soft sediment (Holland-Bartels 1996), suggesting that it may be a more suitable habitat for clams, a preferred sea-otter 
prey in PWS. Thus, it is likely that the energy of sea otter prey per unit area was substantially lower at Knight Island than at Montague Island prior to the spill, when food was presumably limiting at both locations. Furthermore, it is possible that prey energy per unit area would remain lower at Knight than at Montague Island, even if the sea otter population at Knight Island was below carrying capacity and food was no longer limiting with respect to the potential for intrinsic population growth. Therefore, we assessed availability of food in terms of energy available per unit mass of sea otter to account for possible differences in carrying capacity of the 2 study areas. We assume that, while prey energy per unit area may differ between the 2 areas when at carrying capacity, the energy available per unit mass of sea otter would be roughly equivalent. Thus, food limitation at northern Knight Island, especially with respect to the potential for intrinsic population growth, would be indicated by lower or equal energy of prey available per unit mass of sea otter.

Prey items evaluated were clams, crabs, mussels and sea urchins. Independent estimates of sea otter diets made both prior to (Calkins 1978, Estes et al. 1981, Garshelis et al. 1986) and subsequent to the oil spill (Doroff \& Bodkin 1994 and section on 'Rate of consumption of food by sea otters' below) suggest that these prey comprise the vast majority of food consumed by sea otters in PWS. The density and size distributions of prey were estimated from stratified random sampling within each of 2 study areas: Knight and Montague Islands (Fig. 1). Sampling was stratified by depth and was conducted between 1996 and 1998 (Table 1). We collected prey by hand along intertidal strata sampled at low tide or from subtidal strata using
SCUBA. Subtidal clams were sampled using a diveroperated suction dredge (Fukuyama 2000). Not all species or strata were sampled in each year, and we used combined estimates for all years, ignoring possible year-to-year differences.

The prey energy available per unit area within each study area and depth stratum was calculated based on abundance and size distribution of prey. In most instances, all sampled individuals for a particular prey were measured, and sizes of individuals were converted to energy units using size to dry-tissue mass regressions, and estimates of energy per unit drymass. For crabs Telmessus cheiragonus, we did not measure sizes but only counted crabs larger than $44 \mathrm{~mm}$ carapace length (about $50 \mathrm{~mm}$ carapace width), and made conversions from abundance to energy by assuming the average size (carapace width) of crabs was $44 \mathrm{~mm}$. This is a reasonable approximation based on crab size selection in sea otter feeding observations (D. H. Monson pers. obs.).

For all prey, we assumed that sea otters were sizeselective predators, and that only prey above a given size were available. This assumption is supported by direct observations of sea-otter foraging, and by comparisons of sizes of prey eaten vs sizes available in a wide variety of sea otter prey, over a range of habitat types (Estes et al. 1978, Simenstad et al. 1978, Ostfeld 1982, Kvitek \& Oliver 1988, VanBlaricom 1988, Kvitek et al. 1992, Estes \& Duggins 1995). A size cutoff of $20 \mathrm{~mm}$ (length) was used for clams and mussels based on the sizes of clams in collections of sea otter-cracked shells (Kvitek et al. 1992, Fukuyama 2000), the sizes of mussels available to otters (VanBlaricom 1988), and direct foraging observations (J. L. Bodkin \& D. H. Monson pers. obs.). For crabs, we used a $44 \mathrm{~mm}$ carapace

Table 1. Summary of sampling effort for determination of density of sea otter prey at northern Knight Island (KI) and Montague Island (MI). Strata are indicated as: +2.5 to $+0.5 \mathrm{~m}=$ high intertidal $(\mathrm{HI}) ;+0.5$ to $-0.5 \mathrm{~m}=$ low intertidal $(\mathrm{LI}) ;-0.5$ to $-5.0 \mathrm{~m}=\mathrm{very}$ shallow subtidal (VSS) $;-5.0$ to $-10.0 \mathrm{~m}=$ shallow subtidal $(\mathrm{SS}) ;-10.0$ to $-20.0 \mathrm{~m}=$ deep subtidal (DS). All depths are relative to mean lower-low water

\begin{tabular}{|c|c|c|c|c|c|c|}
\hline \multirow[t]{2}{*}{ Prey species } & \multirow[t]{2}{*}{$\begin{array}{c}\text { Strata } \\
\text { sampled }\end{array}$} & \multicolumn{2}{|c|}{$\begin{array}{l}\text { No. sites } \\
\text { sampled } \\
\text { per area }\end{array}$} & \multirow[t]{2}{*}{$\begin{array}{c}\text { Years } \\
\text { sampled }\end{array}$} & \multirow[t]{2}{*}{$\begin{array}{c}\text { No. quadrats or } \\
\text { transects sampled } \\
\text { per site and stratum }\end{array}$} & \multirow[t]{2}{*}{$\begin{array}{l}\text { Quadrat or } \\
\text { transect size } \\
\text { (m) }\end{array}$} \\
\hline & & KI & MI & & & \\
\hline \multirow[t]{3}{*}{ Protothaca staminea } & LI & 75 & 75 & 1996, 1997, 1998 & 5 & $0.5 \times 0.5 \times 0.1$ deep \\
\hline & SS & 39 & 37 & 1996,1997 & 3-6 (usually 4) & $0.5 \times 0.5 \times 0.3$ deep \\
\hline & DS & 10 & 10 & 1998 & 3-4 (usually 4) & $0.5 \times 0.5 \times 0.3$ deep \\
\hline \multirow[t]{3}{*}{ All other clams } & LI & 45 & 45 & 1997, 1998 & 5 & $0.5 \times 0.5 \times 0.1$ deep \\
\hline & SS & 39 & 37 & 1996,1997 & 3-6 (usually 4) & $0.5 \times 0.5 \times 0.1$ deep \\
\hline & DS & 10 & 10 & 1998 & 3-4 (usually 4) & $0.5 \times 0.5 \times 0.1$ deep \\
\hline Telmessus cheiragonus & LI, VSS, SS & 60 & 59 & 1996,1997 & 1 & $50 \times 1$ \\
\hline Mytilus trossulus & $\mathrm{HI}$ & 112 & 107 & 1996,1997 & 10 & $0.22 \times 0.22$ \\
\hline \multirow{2}{*}{$\begin{array}{c}\text { Strongylocentrotus } \\
\text { droebachiensis }\end{array}$} & LI & 75 & 74 & 1996, 1997, 1998 & 1 & $50 \times 0.5$ \\
\hline & VSS, SS & 60 & 59 & 1996,1997 & 1 & $50 \times 0.5$ \\
\hline
\end{tabular}


Table 2. Size to mass and energy to mass relationships for sea otter prey and the source used to quantify these relationships. Sources are as follows: $\mathrm{A}=$ our estimate; $\mathrm{B}=$ Wacasey \& Atkinson (1987); C = Cummins \& Wuycheck (1971); D = mean of 43 bivalve species from Cummins \& Wuycheck (1971)

\begin{tabular}{|c|c|c|c|c|}
\hline Prey Species & Dry mass (mg) vs size (mm) & Source & Energy ( $\mathrm{J} \mathrm{mg}^{-1}$ dry mass) & Source \\
\hline Clinocardium spp. & Mass $=0.000079 \times$ length $^{(2.579)}$ & A & 18.88 & $\mathrm{~B} / \mathrm{C}$ \\
\hline Diplodonta spp. & Mass $=0.000009 \times$ length $^{(3.186)}$ & $\mathrm{A}$ & 18.85 & $\mathrm{D}$ \\
\hline Humilaria kennerleyi & Mass $=0.000018 \times$ length $^{(2.920)}$ & A & 18.85 & $\mathrm{D}$ \\
\hline Macoma spp. & Mass $=0.000006 \times$ length $^{(3.147)}$ & $\mathrm{A}$ & 17.99 & B \\
\hline Mya truncata & Mass $=0.000035 \times$ length $^{(2.903)}$ & A & 13.90 & B \\
\hline Protothaca staminea & Mass $=0.000098 \times$ length $^{(2.432)}$ & A & 22.52 & A \\
\hline Saxidomus gigantea & Mass $=0.000100 \times$ length $^{(2.555)}$ & $\mathrm{A}$ & 18.81 & A \\
\hline Other clams & $\begin{array}{l}\text { Variable-based on relationships } \\
\text { of similar-shaped species }\end{array}$ & A & $18.80-20.2$ & $\mathrm{~A}, \mathrm{~B}, \mathrm{C}$ \\
\hline Telmessus cheiragonus & Mass $=0.000046 \times$ length $^{(3.354)}$ & A & 11.94 & A \\
\hline Mytilus trossulus & Mass $=0.000011 \times$ length $^{(2.843)}$ & A & 17.33 & A \\
\hline Strongylocentrotus droebachiensis & Mass $=0.000650 \times$ test diameter ${ }^{(2.5187)}$ & A & 3.70 & $\mathrm{~A}$ \\
\hline
\end{tabular}

Table 3. Benthic areas $\left(\mathrm{km}^{2}\right)$ within depth strata in the study areas at northern Knight Island (KI) and Montague Island (MI)

\begin{tabular}{|lcc|}
\hline \multirow{2}{*}{$\begin{array}{l}\text { Depth stratum (m relative to } \\
\text { mean lower-low water) }\end{array}$} & \multicolumn{2}{c|}{ Area $\left(\mathrm{km}^{2}\right)$} \\
& $\mathrm{KI}$ & $\mathrm{MI}$ \\
\hline+2.8 to +0.5 & 0.59 & 1.92 \\
+0.5 to -0.5 & 0.39 & 1.57 \\
-0.5 to -5.0 & 1.71 & 7.16 \\
-5.0 to -10.0 & 2.36 & 5.88 \\
-10.0 to -20.0 & 8.27 & 10.66 \\
-20.0 to -100.0 & 13.54 & 46.22 \\
Total & 26.86 & 73.41 \\
\hline
\end{tabular}

length (approximately $50 \mathrm{~mm}$ carapace width) lower limit based primarily on feeding observations. A size of $15 \mathrm{~mm}$ test diameter was used for sea urchins based on the lower limit of sea urchins, size in sea otter scats (Estes \& Duggins 1995).

For the more abundant prey species, we developed dry mass to size relationships, using a subset of animals collected (Table 2). In other cases (all of which were clams) we substituted dry mass to size regressions using similarly shaped species. Energy conversions were based on our calorimetry of a subsample or values reported in the literature.

Weighted mean values for energy of prey per unit area $\left(\mathrm{kJ} \mathrm{m}^{-2}\right)$ were computed based on the calculated mean energy of prey per unit area in each stratum in each study area and the size $\left(\mathrm{km}^{2}\right)$ of each stratum in each study area (Table 3). For strata to a depth of $10 \mathrm{~m}$, the stratum size was determined based on a sampling of distances between stratum boundaries at systematically selected shoreline sites and the total shoreline length. The area within the 20 to $100 \mathrm{~m}$ depth stratum was determined from a GIS analysis of bathymetric charts. The area of the 10 to $20 \mathrm{~m}$ depth stratum was determined by subtraction. Not all species were sampled in each depth stratum, either because we had some prior knowledge of the depth distribution of species (e.g. Mytilus trossulus occurs almost exclusively in the upper intertidal region in PWS) or because of logistical considerations. None of the species were sampled at depths $>20 \mathrm{~m}$ because of our inability to safely sample these depths using SCUBA. Extrapolations to depths up to $100 \mathrm{~m}$ using data from the 10 to $20 \mathrm{~m}$ depth stratum may have introduced bias. There are no quantitative estimates of densities of various sea otter prey at depths greater than $20 \mathrm{~m}$, and we cannot evaluate the direction or extent of these potential biases. Assumptions regarding the abundance estimates for unsampled strata are given in Table 4. It was assumed that otters seldom feed at depths greater than $100 \mathrm{~m}$, as confirmed by feeding observations (J. L. Bodkin \& D. H. Monson unpubl. obs.).

Prey energy available per unit mass of sea otter was estimated as:

prey energy per unit mass of sea otter $\left(\mathrm{kJ} \mathrm{kg}^{-1}\right.$ of otter $)=\left(\right.$ prey energy density $\left[\mathrm{kJ} \mathrm{m}^{-2}\right] \times$ sea otter sampling area $\left[\mathrm{m}^{2}\right] \times$ the proportion of the sea otter sampling area that is less than $100 \mathrm{~m}$ depth)/(sea otter abundance $\times$ avg. mass of a sea otter [kg])

Sea otter abundance was the mean of 1996, 1997, and 1998 aerial survey estimates (replicated in each year) at Knight and Montague Islands (Dean et al. 2000). The area over which otters were surveyed (168 and $90 \mathrm{~km}^{2}$ at Knight and Montague Islands respectively) was larger than the prey sampling area (27 and 
$73 \mathrm{~km}^{2}$ ). We assumed that prey abundance within the smaller prey sampling area was representative of the larger sea otter sampling area. The average mass of a sea otter $(22.85 \mathrm{~kg})$ was determined from a sample of 145 individuals captured between 1996 and 1998. This estimate, based on a pooled sample from northern Knight and Montague Islands, was used in the calculation of prey energy available per unit mass of sea otter in each area.

Variances and confidence intervals for both prey energy per unit area and prey energy per unit mass of sea otter were calculated using formulae for estimating the variances of products of an independent variable and a constant, and of ratios of 2 independent means (Goodman 1970). The null hypotheses that prey energy per unit area and prey energy per unit mass of sea otter at Knight Island were equal to those at Montague Island were tested using a 1-tailed z-test (Snedecor \& Cochran 1969).

Energy requirements of sea otters at Knight and Montague Islands were determined based on sea otter abundance, the average energy requirement of a sea otter, and the average mass of a sea otter. The energy requirement of $1019 \mathrm{~kJ} \mathrm{~kg}^{-1} \mathrm{~d}^{-1}$ was an average of several published values (Kenyon 1969, Fausett 1976, Costa 1982). Estimates of yearly energy requirements were compared to estimates of yearly production of prey. The latter assumed that the ratio of yearly net production to standing stock (the P:B ratio) for prey was 2.0. This was based on values given for several benthic invertebrates in PWS (Feder \& Jewett 1987).

There are no comparable pre-spill estimates of prey availability for PWS, and no estimates for areas outside PWS. However, Kvitek et al. (1992) gave standing stocks (wet meat mass) of bivalves from areas where sea otters were feeding at locations around Kodiak Island with various histories of sea otter colonization. We converted these values to energy units assuming that dry meat mass was $18.7 \%$ of wet meat mass (based on the average for clams collected in our study) and an energy density of $18.8 \mathrm{~kJ} \mathrm{~g}^{-1}$ dry meat mass (based on our data and on values for energy density of
Saxidomus gigantea, the numerically dominant clam). We compared these values to similar estimates of prey energy per unit area from sea otter feeding sites at northern Knight Island (5 sites) and Montague Island (3 sites) sampled in 1997. Sampling and estimation of prey energy per unit area were as described above for systematic sites.

Rate of consumption of food by sea otters. The average prey consumption rate by sea otters in each study area was calculated based on measurements of (1) the time of an average dive plus the time interval between dives, (2) the proportion of dives that were successful in obtaining food, (3) the type, number, and size of prey obtained on each successful dive, and (4) the average energy content of each prey. Numbers 1 to 3 above were based on direct foraging observations made from sites along the shoreline using a 50 to $80 \times$ magnification spotting scope while 4 was based on estimates from sea-otter-cracked shells from sea otter foraging sites (see below). Observations were made during daylight hours in June through August 1996, 1997 and 1998. A total of 117 foraging observation sessions were conducted at Knight Island, and 113 were conducted at Montague Island. An average of 8 dives per session was observed in each area. Energy conversions were made based on expressions given in Table 3 , or from values given in Cummins \& Wuycheck (1971) or Wacasey \& Atkinson (1987).

Observers could distinguish prey type (clam, mussel, crab, sea urchin, etc.) and the size class $(<4,4$ to 8 , or $>8 \mathrm{~cm}$ in length) of each prey, but could not accurately estimate size or, in the case of clams, species. Therefore, we estimated the species composition of clam prey and average size of each species of clam based on collections of sea-otter-cracked shells from sea otter foraging sites. This method is based on the unique way in which sea otters feed and the ability of divers to distinguish otter-cracked shells from others (Kvitek et al. 1988, 1992, Fukuyama 2000). A total of 33 and 30 foraging sites were sampled at Knight and Montague Islands respectively in summer 1996 and 1997. An average of 11 and 20 otter-cracked clam shells was col-

Table 4. Assumptions regarding sea otter prey densities in unsampled depth strata

\begin{tabular}{|c|c|}
\hline Prey species & Assumption \\
\hline Protothaca staminea & Density $=0$ below $20 \mathrm{~m}$ depth and above $+0.5 \mathrm{~m}$ \\
\hline $\begin{array}{l}\text { Telmessus cheiragonus and } \\
\text { Strongylocentrotus droebachiensis }\end{array}$ & Densities at depths below $10 \mathrm{~m}$ are equal to densities in the -5 to $-10 \mathrm{~m}$ depth stratum \\
\hline Mytilus trossulus & $\begin{array}{l}\text { Density }=0 \text { in the }+2.8 \text { to } 0.5 \mathrm{~m} \text { depth stratum } \\
\text { Density }=0 \text { below the }+0.5 \mathrm{~m} \text { stratum }\end{array}$ \\
\hline All others & $\begin{array}{l}\text { Densities at depths below } 20 \mathrm{~m} \text { are equal to densities in the }-10 \text { to }-20 \mathrm{~m} \text { depth stratum } \\
\text { Density }=0 \text { in the }+2.8 \text { to } 0.5 \mathrm{~m} \text { depth stratum }\end{array}$ \\
\hline
\end{tabular}


lected and measured at each site respectively. Only newly deposited shells (based on color and degree of epifaunal growth) were included.

We tested the hypothesis of no difference in consumption rate between Knight and Montague Islands using a Monte Carlo re-sampling method (Manly 1991). We used the mean and variance estimate for each of the observable foraging attributes used in the calculation of consumption rates (dive times, number and size of prey, etc.) to estimate a statistical distribution for each attribute. Initially data from both study sites were combined to represent a null distribution of no difference between populations at Knight and Montague Islands. A sample size of 117 (Knight) and 113 (Montague) was randomly selected (representing the number of foraging sessions observed in each area) from the distribution of each attribute, the averages of these were computed, a consumption rate calculated for each area, and a difference in consumption rate found. This process was repeated 1000 times to create a Monte Carlo simulation of the null distribution of differences. The observed difference in consumption rates was estimated using the site-specific mean values for each attribute to derive 1 consumption rate for each area. The statistical significance of the difference in consumption rate was estimated by the proportion of the null distribution of differences that was greater than the observed difference. This can essentially be interpreted in the same manner as the probability associated with a $t$-statistic testing the hypothesis of no difference between means. We also calculated $95 \%$ Monte Carlo confidence intervals for consumption rates. The Monte Carlo procedure included drawing a random sample from the site-specific distribution for each attribute of sample size 117 and 113, for Knight and Montague respectively. We again calculated the mean values to estimate the new consumption rate and repeated the process 1000 times for each area. Confidence limits were estimated by the 2.5 and $97.5 \%$ points in the Monte Carlo distribution of consumption rates.

The consumption rates for sea otters at Knight and Montague Islands in 1996 to 1998 were contrasted with comparable data from other PWS sites (Garshelis et al. 1986) and from Kodiak Island collected prior to the spill. Means and 95\% confidence intervals were estimated for consumption rates at Kodiak largely using published data from these sites as inputs. Calculations were made in the same manner described above for Knight and Montague Islands. Foraging data for Kodiak Island (Doroff \& DeGange 1994, A. R. DeGange unpubl. data) were collected in a manner similar to those described for PWS. Size distributions of clams at Kodiak Island were based on shell litter collections (Kvitek et al. 1992).

Morphometrics. Age-adjusted body mass and mass to length ratios were compared between sea otters captured from northern Knight, Montague, and Kodiak Islands. Animals at Knight and Montague Islands were captured in 1996, 1997, and 1998 using either tangle nets or diver-operated modified Wilson traps (Bodkin et al. 2002). The sex, mass, and body length (from the tip of the nose to the tip of the tailbone) of each animal was determined and a tooth (premolar) was extracted prior to the animal's release. Each tooth was analyzed to estimate the age of the sea otter based on the number of cementum layers (Garshelis 1984, Bodkin et al. 1997). This analysis provides ages accurate to $\pm 1 \mathrm{yr}$ on average. The Kodiak data were collected in 1986 and 1987 using methods similar to those described above (Monson et al. 2000b, Monson \& DeGange 1995). The Kodiak site was recently occupied by sea otters (within 5 to $15 \mathrm{yr}$ prior to sampling) and there was abundant food.

Table 5. Mean energy per unit area $\left(\mathrm{kJ} \mathrm{m}^{-2}\right)$ for sea otter prey at northern Knight and Montague Islands, 1996-1998. CI: confidence interval

\begin{tabular}{|c|c|c|c|c|c|c|}
\hline \multirow[t]{2}{*}{ Taxa } & \multicolumn{2}{|c|}{ Knight Island } & \multicolumn{2}{|c|}{ Montague Island } & \multirow[t]{2}{*}{$z$} & \multirow{2}{*}{$\mathrm{p}$} \\
\hline & Mean & $95 \% \mathrm{CI}$ & Mean & $95 \% \mathrm{CI}$ & & \\
\hline Humilaria kennerleyi & 31.66 & \pm 67.27 & 16.76 & \pm 39.00 & 0.38 & 0.35 \\
\hline Mya truncata & 15.82 & \pm 49.09 & 31.47 & \pm 97.36 & -0.28 & 0.61 \\
\hline Other clams & 6.73 & \pm 26.01 & 31.09 & \pm 57.60 & -0.76 & 0.78 \\
\hline Mytilus trossulus & 6.44 & \pm 0.83 & 14.62 & \pm 1.48 & -9.43 & $<0.01$ \\
\hline Saxidomus gigantea & 4.40 & \pm 22.88 & 22.04 & \pm 41.68 & -0.73 & 0.77 \\
\hline Protothaca staminea & 3.99 & \pm 14.13 & 0.99 & \pm 4.04 & 0.40 & 0.34 \\
\hline Telmessus cheiragonus & 1.62 & \pm 3.89 & 0.34 & \pm 1.10 & 0.33 & 0.37 \\
\hline Clinocardium spp. & 1.89 & \pm 4.53 & 7.66 & \pm 23.83 & -0.47 & 0.68 \\
\hline Macoma spp. & 1.29 & \pm 3.65 & 23.34 & \pm 63.76 & -0.68 & 0.75 \\
\hline Diplodonta spp. & 0.32 & \pm 1.33 & 0.96 & \pm 5.62 & -0.22 & 0.59 \\
\hline Strongylocentrotus droebachiensis & 0.03 & \pm 0.23 & 0.03 & \pm 0.23 & 0.01 & 0.50 \\
\hline Total & 74.20 & \pm 91.58 & 149.30 & \pm 144.01 & -0.86 & 0.81 \\
\hline
\end{tabular}


Analyses were conducted for females from 1 to $4 \mathrm{yr}$ of age that did not have dependent pups with them at the time of capture. We restricted the analyses to females because there were too few males captured for the purpose of comparison. Older females were excluded because of possible confounding effects of having a large number of pregnant females among older individuals, and because the effects of a limited food supply were expected to have their greatest impact on younger animals that are generally poorer competitors. Higher starvation-caused mortality in young animals has been suggested for sea otters (Kenyon 1969) and demonstrated for other large mammals (Choquenot 1990, Virgil \& Messier 1997). Variation in survival of immature individuals accounts for most of the variation in rates of population increase for marine mammals (Eberhardt \& Siniff 1977).

We tested the null hypotheses of no difference between age-adjusted mass and mass to length ratio using an analysis of covariance. Age classes used were $1,2,3$, and 4 yr. Areas were contrasted using pairwise comparisons of least-square means.

\section{RESULTS}

\section{Food availability}

The mean energy content of sea-otter prey per unit area was nearly twice as high at Montague as at Knight Island (Table 5). This was primarily the result of higher energy per unit area for Macoma spp., Мya truncata, Saxidomus gigantea, Mytilus trossulus, and 'other clams' at Montague Island. However, among individual species, only the energy per unit area of $M$. trossulus differed significantly between areas $(\mathrm{p}<$ 0.01 ), and there was no significant difference between areas for the energy per unit areas summed over all sea otter prey $(p=0.81)$.

The relative proportions of total energy contributed by each species differed between areas (Table 5). At Knight Island, the majority of energy available was from Humilaria kennerleyi (43\%) and Mya truncata (21\%). At Montague Island, 'other clams', M. truncata, and Macoma spp. contributed 21, 20, and $16 \%$ respectively.

The prey energy per unit mass of sea otter was 4.8 times higher at Knight than at Montague Island (Table 6). However, we failed to reject the null hypothesis that energy per unit mass of sea otter was equal within the 2 areas $(z=1.19, p=0.12)$. The estimated annual production of prey energy at Knight Island $\left(1.6 \times 10^{10} \mathrm{~kJ} \mathrm{yr}^{-1}\right)$ was about 26 times higher than that required to support the sea-otter population there $\left(6.1 \times 10^{8} \mathrm{~kJ} \mathrm{yr}^{-1}\right)$. At Montague Island, the estimate of

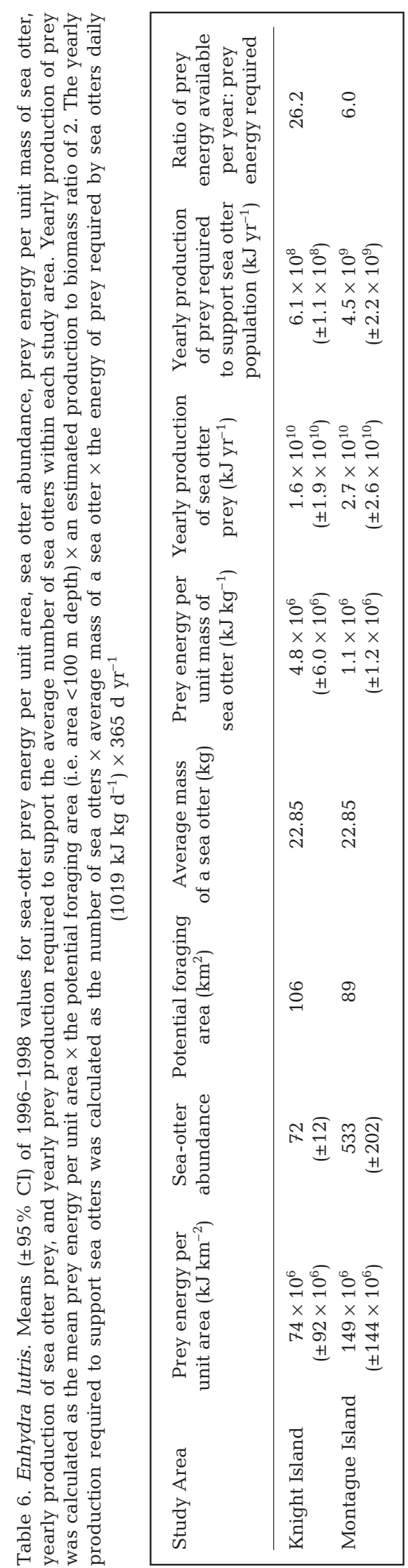


Table 7. Comparisons of clam densities $\left(\mathrm{kJ} \mathrm{m}^{-2}\right)$ at sea otter feeding sites at Kodiak, Knight, and Montague Islands. Kodiak Island data are from Kvitek et al. (1992). Data for otter-free sites Kodiak Island are from randomly selected sampling areas. PWS: Prince William Sound

\begin{tabular}{|llclrl|}
\hline Region & \multicolumn{1}{c}{$\begin{array}{c}\text { Areas within } \\
\text { region }\end{array}$} & Year & Sea otter population status & $\begin{array}{c}\text { Clam energy } \\
\text { per unit area } \\
\left(\mathrm{kJ} \mathrm{m}^{-2}\right)\end{array}$ & $\begin{array}{c}\text { Dominant } \\
\text { clam species }\end{array}$ \\
\hline Kodiak & 6 otter-free sites & $1987-88$ & None & 12958 & Saxidomus gigantea \\
Kodiak & 6 frontal sites & $1986-88$ & Newly occupied & 8384 & Saxidomus gigantea \\
Kodiak & 5 intermediate sites & $1986-87$ & Occupied 5-15 yr & 4008 & Saxidomus gigantea \\
Kodiak & 2 long occupied sites & 1987 & Occupied $>25 \mathrm{yr}$ & 591 & Saxidomus gigantea \\
PWS & Montague Island & $1996-98$ & Occupied $>25 \mathrm{yr}$ & 228 & Mya truncata \\
PWS & Knight Island & $1996-98$ & Long occupied, reduced in 1989 & 85 & Humilaria kennerleyi \\
& & & & & \\
\hline
\end{tabular}

Table 8. Enhydra lutris. Means ( \pm 1 SD) for feeding data for sea otters at northern Knight and Montague Islands, 1996-1997. A total of 117 and 113 sessions were observed at Knight and Montague Islands respectively, with an average of 8 dives observed in each session within both areas

\begin{tabular}{|c|c|c|c|}
\hline Variable & Units & Knight Island & Montague Island \\
\hline Success rate & $\%$ of dives in which & & \\
\hline Clam-mussel dives & prey were captured & 90.3 & 88.3 \\
\hline Non-clam-mussel dives & & 80.7 & 78.8 \\
\hline Time per dive (dive time + surface time) & $\mathrm{s}$ & $162( \pm 66)$ & $121( \pm 48)$ \\
\hline Successful & & & \\
\hline Unsuccessful & & $111( \pm 43)$ & $87( \pm 35)$ \\
\hline Prey composition & $\%$ of successful dives & & \\
\hline Clams & & 72 & 80 \\
\hline Mussels & & 14 & 9 \\
\hline Crabs & & 3 & 4 \\
\hline Other & & 11 & 7 \\
\hline $\begin{array}{l}\text { Number of individuals } \\
\text { per successful dive }\end{array}$ & No. ind. & & \\
\hline Clams & & $2.43( \pm 0.77)$ & $2.12( \pm 0.30)$ \\
\hline Mussels & & $11.25( \pm 4.25)$ & $8.14( \pm 2.13)$ \\
\hline Crabs & & $1.28( \pm 0.33)$ & $1.04( \pm 0.07)$ \\
\hline Other & & $2.90( \pm 1.66)$ & $2.48( \pm 2.44)$ \\
\hline Energy per prey item & $\mathrm{kJ}$ & & \\
\hline Clams & & $51( \pm 16.2)$ & $36( \pm 17.6)$ \\
\hline Mussels & & $5( \pm 0.8)$ & $5( \pm 0.8)$ \\
\hline Crabs & & $505( \pm 50.7)$ & $274( \pm 27.2)$ \\
\hline Other & & $17( \pm 1.7)$ & $17( \pm 1.7)$ \\
\hline
\end{tabular}

Table 9. Percentage of clams by species, mean size of each species $( \pm 1 \mathrm{SD})$, and percentage of total available prey energy contributed by each prey species in sea-otter-cracked shells from sea otter foraging sites at northern Knight (KI; $\mathrm{n}=33$ ) and Montague Islands $(\mathrm{MI} ; \mathrm{n}=30)$. An average of 11 and 20 recently cracked clam shells per site were collected at Knight and Montague respectively

\begin{tabular}{|c|c|c|c|c|c|c|}
\hline \multirow[t]{2}{*}{ Clam species } & \multicolumn{2}{|c|}{ \% (by no. ind.) } & \multicolumn{2}{|c|}{ Mean size (mm) } & \multicolumn{2}{|c|}{ \% (by energy) } \\
\hline & KI & MI & KI & MI & KI & MI \\
\hline Saxidomus gigantea & 46.2 & 12.9 & $61.6(7.1)$ & $56.8(9.8)$ & 58.7 & 23.7 \\
\hline Protothaca staminea & 8.4 & 4.1 & $49.6(8.6)$ & $38.2(8.1)$ & 5.3 & 2.1 \\
\hline Macoma spp. & 11.2 & 5.6 & $45.3(9.7)$ & $42.0(11.7)$ & 3.3 & 2.4 \\
\hline Clinocardium spp. & 3.6 & 18.3 & $42.8(16.2)$ & $39.5(5.9)$ & 2.2 & 8.7 \\
\hline Humilaria kennerleyi & 10.9 & 11.1 & $47.3(12.2)$ & $44.3(5.6)$ & 6.3 & 8.3 \\
\hline Mya truncata & 10.6 & 33.1 & $52.6(10.3)$ & $48.8(5.0)$ & 9.7 & 38.2 \\
\hline Serripes groenlandicus & 5.3 & 2.5 & $64.7(20.2)$ & $53.9(13.7)$ & 11.0 & 4.8 \\
\hline Others & 3.8 & 12.4 & $62.5(13.0)$ & $49.5(4.9)$ & 3.5 & 11.8 \\
\hline
\end{tabular}


Table 10. Enhydra lutris. Estimates of prey consumption and hours spent feeding by independent adult female sea otters (upper and lower $95 \%$ CI). Data from Green Island, Nelson Bay and Orca Inlet are from Garshelis et al. (1986). Feeding data from Kodiak are from Doroff \& DeGange (1994) and A. R. DeGange (unpubl.). Shell length and mass-to-length conversions for Kodiak are from Kvitek et al. (1992) and mass-to-energy conversions were from Kenyon (1969), Cummins \& Wuycheck (1971), and Wacasey \& Atkinson (1987). PWS: Prince William Sound

\begin{tabular}{|c|c|c|c|c|c|}
\hline Region & Area & Year & $\begin{array}{c}\text { Sea otter } \\
\text { population status }\end{array}$ & $\begin{array}{l}\text { Prey consumption } \\
\text { rate }\left(\mathrm{kJ} \mathrm{hr}^{-1}\right)\end{array}$ & $\begin{array}{l}\text { Feeding time } \\
\text { required }\left(\mathrm{h} \mathrm{d}^{-1}\right)\end{array}$ \\
\hline PWS & Orca Inlet & $1980-81$ & Occupied <2 yr & 6134 & $5.0^{\mathrm{b}}$ \\
\hline Kodiak & Kupreanof Strait & $1986-87$ & Occupied < 15 yr & $\begin{array}{c}5100 \\
(4230-6230)\end{array}$ & $\begin{array}{c}4.4^{\mathrm{b}} \\
(3.6-5.3)\end{array}$ \\
\hline Kodiak & Afognak Island & $1986-87$ & Occupied $>25$ yr & $\begin{array}{c}2340 \\
(1482-3337)\end{array}$ & $\begin{array}{c}10.0^{\mathrm{b}} \\
(6.7-15.1)\end{array}$ \\
\hline PWS & Knight Island & $1996-98$ & $\begin{array}{l}\text { Occupied }>25 \mathrm{yr} \\
\text { reduced } 1989-1998\end{array}$ & $\begin{array}{c}2260 \\
(1980-2570)\end{array}$ & $\begin{array}{c}9.9^{\mathrm{b}} \\
(8.7-11.3)\end{array}$ \\
\hline PWS & Nelson Bay & $1980-81$ & Occupied 2 to $3 \mathrm{yr}$ & 2187 & $\begin{array}{c}8.8^{\mathrm{a}} \\
(7.7-9.9)\end{array}$ \\
\hline PWS & Montague Island & $1996-98$ & Occupied > $25 \mathrm{yr}$ & $\begin{array}{c}1900 \\
(1630-2180)\end{array}$ & $\begin{array}{c}11.8^{\mathrm{b}} \\
(10.3-13.7)\end{array}$ \\
\hline PWS & Green Island & $1980-81$ & Occupied $>25$ yr & 1274 & $\begin{array}{c}11.3^{\mathrm{a}} \\
(10.7-11.9)\end{array}$ \\
\hline \multicolumn{6}{|c|}{$\begin{array}{l}\text { a Based on observations of activity from telemetry } \\
{ }^{b} \text { Estimate based on hours required to obtain energy needed for maintenance }\left(1019 \mathrm{~kJ} \mathrm{~kg}^{-1} \mathrm{~d}^{-1}\right) \text {, given the measured prey con- } \\
\text { sumption rate. For Montague and Knight Islands the average sea otter was } 22.5 \mathrm{~kg} \text {, at Orca Inlet most animals were males } \\
\text { and an average size of } 30 \mathrm{~kg} \text { was assumed }\end{array}$} \\
\hline
\end{tabular}

the mean energy available $\left(2.7 \times 10^{10} \mathrm{~kJ} \mathrm{yr}^{-1}\right)$ was only about 6 times that required $\left(4.5 \times 10^{9} \mathrm{~kJ} \mathrm{yr}^{-1}\right)$.

Within sea otter foraging areas, the average clam energy per unit area was substantially higher at Kodiak Island sites sampled by Kvitek et al. (1992) than at either Knight or Montague Islands (Table 7). This was especially true for those Kodiak Island sites where sea otters had only recently become re-established. Frontal areas at Kodiak Island had over 36 times higher densities of clams (in terms of energy per unit area) than Montague Island and over 98 times higher prey energy per unit area than Knight Island. Kodiak sites that were long occupied by sea otters and were considered food-limited had approximately 3 times more $\mathrm{kJ}$ $\mathrm{m}^{-2}$ of clams than Montague, and about 7 times more than Knight Island sites. The dominant clam species (in terms of energy per unit area within sea otter foraging sites) at Knight and Montague Islands were Saxidomus gigantea and Mya truncata respectively. S. gigantea dominated at all Kodiak Island sites.

\section{Rate of consumption}

Clams comprised the majority of the prey energy consumed by sea otters at both Knight and Montague Islands (Table 8). Sea-otter-cracked shell collections indicated that at Knight Island Saxidomus gigantea were the most often taken prey and had the majority of prey energy (Table 9). The species composition in the sea-otter-cracked shell litter at Montague Island was more varied. Most of the prey energy was supplied by Mya truncata and S. gigantea. Mean sizes for all species of clams were slightly larger at Knight than at Montague Island.

Sea otters at Knight Island had a slightly higher proportion of successful dives and took prey that were, on average, of higher energy (Table 8). An average of $90.3 \%$ of dives was successful in obtaining clams or mussels at Knight Island compared to $88.3 \%$ at Montague Island. The average energy provided per prey item was higher at Knight Island for both clams and crabs. At Knight Island, the average clam taken supplied an estimated $51 \mathrm{~kJ}$ compared to $36 \mathrm{~kJ}$ for those taken at Montague Island. Crabs taken had $505 \mathrm{~kJ}$ at Knight Island vs $274 \mathrm{~kJ}$ at Montague Island. For all prey items, sea otters at Knight Island also took more individuals per dive. Factors advantageous to a higher rate of consumption at Knight Island were offset to an extent by a higher average dive time at Knight Island. Dive time plus surface time of successful dives were $33 \%$ longer, and unsuccessful dives were $28 \%$ longer at Knight than at Montague Island. Also, there was a slightly higher proportion of low energy prey (mussels and 'other') taken at Knight Island.

The resulting average consumption rate for sea otters at Knight Island was $2260 \mathrm{~kJ} \mathrm{~h}^{-1}$, about $18.9 \%$ higher than at Montague Island (1900 kJ h${ }^{-1}$; Table 10) and differed significantly between areas $(\mathrm{p}=0.001$, 
1-tailed randomization test). Using these consumption rates, we estimate that the average size female sea otter at Knight Island fed an average of $9.9 \mathrm{~h} \mathrm{~d}^{-1}$ to obtain energy required for maintenance (1019 $\left.\mathrm{kJ} \mathrm{kg}^{-1} \mathrm{~d}^{-1}\right)$. This is lower than the $11.8 \mathrm{~h}$ needed at Montague Island.

The prey consumption rate for sea otters at Montague Island $\left(1900 \mathrm{~kJ} \mathrm{~h}^{-1}\right)$ was slightly higher than that observed at nearby Green Island, PWS, prior to the oil spill (1300 $\mathrm{kJ} \mathrm{h}^{-1}$, Garshelis et al. 1986) (Table 10). Sea otters had occupied the Green Island site for many years and were considered foodlimited. The rate for Knight Island was similar to that observed at Nelson Bay, PWS (Garshelis et al. 1986), an area that was occupied by sea otters for only 2 to $3 \mathrm{yr}$ prior to the surveys of consumption and likely not foodlimited. Both Knight Island (sampled post-spill) and Nelson Bay sea otters had consumption rates that were higher than at Green Island and Montague Islands. Consumption rates were much higher at Orca Inlet in 1980-81, and Kuperanof Strait (Kodiak region) sites in 1986-87 than at all other sites. The Orca Inlet and Kuperanof sites were surveyed only several years after colonization by sea otters, and sea otters there were clearly not food-limited. However, sea otters at a longoccupied site at Afognak Island (Kodiak region) had a consumption rate in the same range as animals from Knight and Montague Islands (Table 10).

\section{Morphometrics}

The age-adjusted body mass and mass to length ratio of 1 to $4 \mathrm{yr}$ old female sea otters (without pups) captured at Knight Island were both significantly higher than for otters from Montague Island in 1996 to 1998 (Table 11). Body mass was $8.7 \%$ higher at Knight, and the mass:length ratio was $6.3 \%$ higher. The difference in the mass to length ratio translates to $1.1 \mathrm{~kg}$ difference for the average young sea otter $(113 \mathrm{~cm}$ in length). Body mass and mass to length ratio were significantly higher at Kodiak Island sites that were only recently colonized by sea otters than at either Knight or Montague Islands. Body mass to length ratio at Kodiak was about $6.5 \%$ higher than at Knight Island and $13.1 \%$ higher than at Montague Island.

\section{DISCUSSION}

The availability of food resources for sea otters was the same, if not greater, at northern Knight as at Mon- tague Island over the period from 1996 to 1998. The rate of consumption of food was significantly higher and the condition of young female sea otters was significantly better at northern Knight than at Montague Island. Furthermore, the mean prey energy per unit area did not differ significantly between areas, and the prey energy available per $\mathrm{kg}$ of sea otter, while not significantly different between the 2 areas, averaged about 4 times higher at Knight Island. Based on the assumption that sea otters were better samplers of their available food supply than we were, and based on the relative lack of precision in estimation of food availability (see discussion below), we suspect that food resources were in fact more available at Knight Island.

Our estimation of food available to sea otters, both in terms of energy of prey per unit area and energy per unit mass of sea otter, were dependent on a number of assumptions. In particular, inaccuracies may have resulted if (1) densities of prey in unsampled habitats (e.g. at depths greater than $20 \mathrm{~m}$ ) were different than we assumed, (2) our sampling missed some widely dispersed, high-density patches of prey, (3) summer sampling misrepresented the average yearly energy density of prey, or (4) there were seasonal movements of sea otters (especially winter decreases in the more exposed Montague Island site) that were undetected by our summer sampling. While the estimates of prey per unit area are clearly imprecise and the estimates of the absolute quantity of prey available may be inaccurate, we have no good reason to suspect that there were biases that may have affected the relative measures of food available at our Knight and Montague Island study sites. Therefore, we feel that they provide a reasonable index of the relative abundance of prey at northern Knight and Montague Islands. There is some evidence that sea otters may move from more exposed areas (like our Montague Island site) in winter (Garshelis et al. 1986) and a winter survey of sea otters at Montague Island conducted in March 1998 (J. L. 
Bodkin unpubl. data) counted $44 \%$ fewer sea otters than in July 1998. However, low light levels during winter resulted in poor precision, and density estimates did not differ significantly between March and July surveys.

Although food was at least as abundant at northern Knight Island as at Montague Island, there was no increase in sea otter population at northern Knight Island between 1993 and 1998, but a significant increase at Montague Island over the same period (Dean et al. 2000). The number of sea otters at Montague Island increased from 335 in 1993 to 623 in 1998, a rate of about $15 \% \mathrm{yr}^{-1}$, but remained almost constant (from 77 in 1993 to 76 in 1998) at northern Knight Island. These data provide evidence that the population of sea otters at northern Knight Island was below its carrying capacity with respect to food resources, and that the lack of growth of the sea otter population at northern Knight Island was due to factors other than the availability of food resources necessary for intrinsic population growth.

There is also demographic evidence that suggests that food was not limiting intrinsic population growth of sea otters at northern Knight Island. The growth of food-limited populations is often constrained because of lower juvenile survival (Choquenot 1991). In the several years after the oil spill, survival rates of juvenile sea otters were lower than pre-spill rates (Monson et al. 2000a) and lower weanling survival was noted in oil impacted vs unimpacted areas (Ballachey et al. 1994). However, in more recent years (including the years 1996 to 1998 in which our study was conducted) survival rates for juveniles returned to pre-spill levels (Monson et al. 2000a). This is consistent with what would be expected under non-food limiting conditions. Also, birth rates of sea otters did not differ between oiled and unoiled portions of PWS (Johnson \& Garshelis 1995, Bodkin et al. 2000). Survival rates of older sea otters decreased with time after the spill (Monson et al. 2000a), but given the better condition of sea otters in northern Knight Island, it is unlikely that the lower survival of older animals was caused by a lack of food.

While there was apparently sufficient food to allow for intrinsic growth of the existing segment of the population at northern Knight Island in 1996 to 1998, there is some question as to whether there was sufficient food to allow for successful immigration. Food appeared at least equally abundant at northern Knight Island compared to Montague Island, but food resources were still substantially lower at both Knight and Montague Islands than in areas recently reoccupied by sea otters (after decades of absence) where food was clearly not limiting. The relative lack of food at Knight and Montague Islands was probably largely the result of predation by sea otters that occupied these sites for several decades prior to the oil spill (Garshelis et al. 1986, Bodkin et al. 2000), but may have been exacerbated at Knight Island due to impacts of the spill on the prey (reviewed in Peterson 2001). Sufficient food resources are a requisite for successful immigration (Estes et al. 1986), and higher densities of food might be required for successful immigration than are required for growth within resident populations. This may especially be the case because food resources are patchy, and new immigrants may not be as efficient at utilizing food resources as resident adult sea otters or pups that learn feeding behavior from their mothers. Thus, it is possible that there may have been sufficient food at northern Knight Island for intrinsic growth, but insufficient food to induce potential immigrants to establish residency. However, age-distribution models suggest that there must have been some net immigration to the northern Knight Island area in order to offset losses due to mortality and maintain the current population density (Monson et al 2000a). Therefore, while the relative short supply of food at Knight Island (compared to areas unoccupied by sea otters for decades) may have been sufficient to curtail net immigration, it apparently did not altogether prevent immigration and does not appear to be a primary cause for the lack of sea otter recovery.

While food resources at northern Knight Island appear sufficient to allow for population growth, they do not appear sufficient to allow for maximum potential population growth as observed in some sea otter populations in newly occupied areas. Sea otter populations that inhabit areas unoccupied by sea otters for several decades prior, and that have unlimited food supplies, can increase at the rate of $25 \% \mathrm{yr}^{-1}$ (Estes 1990, Bodkin et al. 1999). Food resources at both northern Knight and Montague Islands were much lower than in these newly occupied sites, and were likely insufficient to allow for population growth rates near the maximum. Nonetheless, there was clearly sufficient food at both locations for some sea otter population growth, yet we observed growth at Montague Island, but not at northern Knight Island.

It is also possible that the relatively short supply of food at northern Knight Island (again compared to areas unoccupied by sea otters) may have interacted with other factors (e.g. oil-induced mortality or predation) to constrain sea otter population growth, and therefore sea otter recovery. Higher sea otter mortality rates were observed in oil-affected areas of PWS through 1998, perhaps as a result of exposure to oil (Ballachey et al. 2000, Monson et al. 2000a). Furthermore, predation by killer whales (Estes et al. 1998, Hatfield et al. 1998, Garshelis \& Johnson 1999) and other hunters (Bodkin et al. 2001) may have contributed to the lack of recovery. Populations occupying 
habitats with low-potential food supplies are more prone to being regulated at low densities by predation (Messier 1994) or possibly by oil-induced mortality. However, there is little evidence that predation pressure was higher at northern Knight than at Montague Island. Thus, the relative differences in sea otter population growth at northern Knight vs Montague Island, and the lack of recovery of sea otter populations at northern Knight Island were unlikely the result of higher predation rates there.

Based on the equal if not greater availability of prey energy per otter at northern Knight Island than at Montague Island, and based on the increasing population density of sea otters at Montague Island but not at northern Knight Island, we conclude that factors other than food were primarily responsible for lack of recovery of sea otters in the heavily oiled northern Knight Island portion of PWS following the 'Exxon Valdez' oil spill. Evidence presented elsewhere (Ballachey et al. 2000, Monson et al. 2000a, Bodkin et al. 2002) suggests that the recovery was primarily constrained by high rates of mortality and emigration that were linked to continued exposure to oil or persistent sublethal effects of oiling. However, it was also apparent that the potential population growth rate for sea otters at both Knight and Montague Islands was food-limited and the relatively short supply of food may have restricted immigration or interacted with other factors (e.g. predation or oil-induced mortality or emigration) to constrain sea otter recovery at northern Knight Island. Nonetheless, our data suggest that impacts of anthropogenic disturbances on large, often food-limited vertebrate predators may persist in spite of the availability of food resources that is generally sufficient for intrinsic population growth.

Acknowledgements. We thank all of those participants in the Nearshore Vertebrate Predator Project for their enthusiasm, support, and stimulating comments throughout this study. In particular, we thank our project leader, Leslie Holland-Bartels, and co-investigators Brenda Ballachey, Terry Bowyer, Dan Esler, Greg Golet, Dave McGuire, and Lyman McDonald. Invaluable statistical assistance was obtained from John Kern. We also thank all of those who supplied technical support, and especially those who assisted in collecting the data under rigorous field conditions. The work was supported by the Alaska Biological Science Center, Biological Resources Division, US Geological Survey, the Alaska Department of Fish and Game, and the Exxon Valdez Oil Spill Trustee Council. The findings and conclusions presented by the authors, however, are their own and do not necessarily reflect the views or opinions of the supporting organizations.

\section{LITERATURE CITED}

ADEC (Alaska Department of Environmental Conservation) (1989) Impact maps and summary reports of shoreline surveys of the 'Exxon Valdez' spill site, Prince William Sound. Exxon Valdez Oil Spill Trustee Council, Anchorage
ADNR (Alaska Department of Natural Resources \& US Fish and Wildlife Service) (1991) The Exxon Valdez oil spill natural resource damage assessment and restoration: a report on oiling to environmentally sensitive shorelines. Exxon Valdez Oil Spill Trustee Council, Restoration Project Final Report (Restoration Project 95025-99025), US Geological Survey Anchorage

Ballachey BE, Bodkin JL, DeGange AR (1994) An overview of sea otter studies. In: Loughlin TR (ed) Marine mammals and the Exxon Valdez. Academic Press, San Diego, p 47-59

Ballachey BE, Stegeman JJ, Snyder PW, Blundell GM and 10 others (2000) Oil exposure and health of nearshore vertebrate predators in Prince William Sound following the Exxon Valdez oil spill. In: Holland-Bartels LE (ed) Mechanisms of impact and potential recovery of nearshore vertebrate predators following the 1989 Exxon Valdez oil spill. Exxon Valdez Oil Spill Trustee Council, Restoration Project Final Report (Restoration Project 95025-99025), US Geological Survey, Anchorage, AK, p 2.1-2.58

Bayliss P (1985) The population dynamics of red and western gray kangaroos in arid New South Wales, Australia. II. The numerical response function. J Anim Ecol 54:127-135

Bobek B (1977) Summer food as the factor limiting red deer population size. Nature 268:47-49

Bodkin JL, Udevitz MS (1994) An intersection model for estimating sea otter mortality along the Kenai Peninsula. In: Loughlin TR (ed) Marine mammals and the Exxon Valdez. Academic Press, San Diego, p 81-95

Bodkin JL, Ames JA, Jameson RJ, Johnson AM, Matson GM (1997) Estimating age of sea otters with cementum layers in the first premolar. J Wildl Manag 61(3):967-973

Bodkin JL, Ballachey BE, Cronin MA, Scribner KT (1999) Population demographics and genetic diversity in remnant and re-established populations of sea otters. Conserv Biol 13:1278-1385

Bodkin JL, Burdin AM, Ryazanov DA (2000) Age- and sexspecific mortality and population structure in sea otters. Mar Mamm Sci 16:201-219

Bodkin JL, Ballachey BE, Dean TA, Fukuyama AK and 5 others (2002) Sea otter population status and the process of recovery following the 1989 'Exxon Valdez' oil spill. Mar Ecol Prog Ser 241:237-253

Calkins DG (1978) Feeding behavior and major prey species of the sea otter, Enhydra lutris, in Montague Strait, Prince William Sound, Alaska. US Fish Bull 76:125-131

Choquenot D (1990) Rate of increase for populations of feral donkeys in northern Australia. J Mammal 71:151-155

Choquenot D (1991) Density-dependent growth, body condition and demography in feral donkeys: testing the food hypothesis. Ecology 72:805-813

Coats DA, Fukuyama AK, Skalski JR, Kimura S, Shigenaka G, Hoff R (1999) Monitoring of biological recovery of Prince William Sound intertidal sites impacted by the Exxon Valdez oil spill-1997 Biological Monitoring Survey. NOAA Tech Memo NOS OR\&R 1, Seattle, p 73

Costa DP (1982) Energy, nitrogen, and electrolyte flux and sea water drinking in the sea otter Enhydra lutris. Physiol Zool 55:35-44

Cummins KW, Wuycheck JC (1971) Caloric equivalents for investigations in ecological energetics. Mitt Int Ver Limnol $18: 160$

Dean TA, SC Jewett (2001) Habitat specific recovery of shallow subtidal communities following the Exxon Valdez oil spill. Ecol Appl 11:1456-1471

Dean TA, Jewett SC, Laur DR, Smith RO (1996) Injury to epibenthic invertebrates resulting from the Exxon Valdez 
oil spill. In: Rice SD, Spies RB, Wolfe DA, Wright BA (eds) Proc Exxon Valdez Oil Spill Symp. Am Fish Soc Symp 18:424-439

Dean TA, Bodkin JL, Jewett SC, Monson DH, Jung D (2000) Changes in sea urchins and kelp following reduction in sea otter density as a result of the Exxon Valdez oil spill. Mar Ecol Prog Ser 199:281-291

Doroff AM, Bodkin JL (1994) Sea otter foraging behavior and hydrocarbon levels in prey. In: Loughlin T (ed) Marine mammals and the Exxon Valdez. Academic Press, San Diego, p 193-208

Doroff AM, DeGange AR (1994) Sea otter, Enhydra lutris, prey composition and foraging success in the northern Kodiak Archipelago. US Fish Bull 92:704-710

Driskell WB, Fukuyama AK, Houghton JP, Lees DC, Mearns AJ, Shigenaka G (1996) Recovery of Prince William Sound intertidal infauna from Exxon Valdez oiling and shoreline treatments, 1989 through 1992. In: Rice SD, Spies RB, Wolfe DA, Wright BA (eds) Proc Exxon Valdez Oil Spill Symp. Am Fish Soc Symp 18:362-378

Eberhardt LL, Siniff DB (1977) Population dynamics and marine mammal management policies. J Fish Res Board Can 34:183-190

Estes JA (1990) Growth and equilibrium in sea otter populations. J Anim Ecol 59:385-401

Estes JA (1996) The influence of large, mobile predators in aquatic food webs: examples from sea otters and kelp forests. In: Greenstreet SPR, Taster ML (eds) Aquatic predators and their prey. Fishing News Books, Oxford, p 65-72

Estes JA, Duggins DO (1995) Sea otters and kelp forests in Alaska: generality and variation in a community ecological paradigm. Ecol Monogr 65:75-100

Estes JA, Smith NS, Palmisano JF (1978) Sea otter predation and community organization in the western Aleutian Islands, Alaska. Ecology 59:822-833

Estes JA, Jameson RJ, Johnson AM (1981) Food selection and some foraging tactics of sea otters. In: Chapman JA, Pursley D (eds) The worldwide furbearer conference proceedings. University of Maryland Press, Bethesda, MD, p 606-641

Estes JA, Underwood KE, Karmann MJ (1986) Activity-time budgets of sea otters in California. J Wildl Manag 50: 626-636

Estes JA, Tinker MT, Williams TM, Doak DF (1998) Killer whale predation on sea otters linking oceanic and nearshore ecosystems. Science 282:473-476

Fausett J (1976) Assimilation efficiency of captive sea otters, Enhydra lutris. MA thesis, California State University, Long Beach

Feder HM, Jewett SC (1987) The subtidal benthos. In: Hood DW, Zimmerman ST (eds) The Gulf of Alaska: physical environment and biological resources. Report to US Department of Commerce and US Department of the Interior, Washington, DC, p 347-396

Freeland WJ, Choquenot D (1990) Determinants of herbivore carrying capacity: plants, nutrients and Equus asinus in northern Australia. Ecology 71:589-597

Fryxell JM (1987) Food limitation and demography of a migratory antelope, the white-eared kob. Oecologia 72 : 83-91

Fukuyama AK (2000) The ecology of bivalve communities in Prince William Sound, Alaska: influence of the Exxon Valdez oil spill and predation by sea otters. PhD thesis, University of Washington, Seattle

Fukuyama AK, Shigenaka G, Hoff RZ (2000) Effects of residual Exxon Valdez oil on intertidal Protothaca staminea: mortality, growth, and bioaccumulation of hydrocarbons in transplanted clams. Mar Poll Bull 40:1042-1050

Galt JA, Lehr WJ, Payton DL (1991) Fate and transport of the Exxon Valdez oil spill. Environ Sci Technol 25:202-209

Garrott RA, Eberhardt LL, Burn DM (1993) Mortality of sea otters in Prince William Sound following the Exxon Valdez oil spill. Mar Mamm Sci 9:343-359

Garshelis DL (1984) Age estimation of living otters. J Wildl Manag 48:456-463

Garshelis DL (1997) Sea otter mortality estimated from carcasses collected after the Exxon Valdez oil spill. Conserv Biol 11:905-916

Garshelis DL, Johnson CB (1999) Otter-eating Orcas. Science 283:175

Garshelis DL, Garshelis JA, Kimker AT (1986) Sea otter time budgets and prey relationships in Alaska. J Wildl Manag 50:637-647

Gilfillan ES, Page DS, Harner EJ, Boehm PD (1995) Shoreline ecology program for Prince William Sound, Alaska, following the Exxon Valdez oil spill. Part 3. Biology. In: Wells PG, Butler JN, Hughes JS (eds) Exxon Valdez oil spill: fate and effects in Alaskan waters. ASTM STP 1219. Am Soc Testing Materials, Philadelphia, p 398-443

Goodman L (1970) On the exact variance of products. Am Stat Assoc J 55:708-713

Gorbics CS, Bodkin JL (2001) Stock structure of sea otters Enhydra lutris kenyoni in Alaska. Mar Mamm Sci 17: 632-647

Hatfield BB, Marks D, Tinker MT, Nolan K, Pierce J (1998) Attacks on sea otters by killer whales. Mar Mamm Sci 14: 888-894

Highsmith RC, Rucker TL, Stekoll MS, Saupe SM, Lindeberg MR, Jenne RN, Erickson WP (1996) Impact of the Exxon Valdez oil spill on intertidal biota. In: Rice SD, Spies RB, Wolfe DA, Wright BA (eds) Proc Exxon Valdez Oil Spill Symp. Am Fish Soc Symp 18:212-237

Holland-Bartels, LE (1996) Mechanisms of impact and potential recovery of nearshore vertebrate predators: restoration project 95025 annual report. Exxon Valdez Oil Spill Trustee Council, Restoration Project Final Report (Restoration Project 95025-99025), US Geological Survey Anchorage, AK

Houghton JP, Lees DC, Driskell WB, Lindstrom SC, Mearns AJ (1996) Recovery of Prince William Sound intertidal epibiota from Exxon Valdez oiling and shoreline treatments, 1989 through 1992. In: Rice SD, Spies RB, Wolfe DA, Wright BA (eds) Proc Exxon Valdez Oil Spill Symp. Amer Fish Soc Symp 18:379-411

Hurlbert SJ (1984) Pseudoreplication and the design of ecological field studies. Ecol Monogr 54:187-211

Jewett SC, Dean TA, Smith RO, Blanchard A (1999) The 'Exxon Valdez' oil spill: impacts and recovery in the softbottom benthic community in and adjacent to eelgrass beds. Mar Ecol Prog Ser 185:59-83

Johnson CB, Garshelis DL (1995) Sea otter abundance, distribution, and pup production in Prince William Sound following the Exxon Valdez oil spill. In: Wells PG, Butler JN, Hughes JS (eds) Exxon Valdez oil spill: fate and effects in Alaskan waters. ASTM STP 1219. Am Soc Testing Materials, Philadelphia, p 894-929

Kenyon KW (1969) The sea otter in the eastern Pacific Ocean. North American Fauna 68:1-352

Kvitek RG, Oliver JS (1988) Sea otter foraging habits and effects on prey populations and communities in soft bottom environments. In: VanBlaricom GR, Estes JA (eds) The community ecology of sea otters. Springer-Verlag, Berlin, p 22-47 
Kvitek RG, Fukuyama AK, Anderson BS, Grimm BK (1988) Sea otter foraging on deep burrowing bivalves in a California coastal lagoon. Mar Biol 98:157-167

Kvitek RG, Oliver JS, DeGange AR, Anderson BS (1992) Changes in Alaska soft-bottom prey communities along a gradient in sea otter predation. Ecology 73:413-428

Lensink CJ (1962) The history and status of sea otters in Alaska. PhD thesis, Purdue University, IN

Manly BFJ (1991) Randomization and Monte Carlo methods in biology. Chapman \& Hall, London

Messier F (1994) Ungulate population models with predation: a case study with the North American moose. Ecology 75: 478-488

Monson DH, DeGange AR (1995) Reproduction, preweaning survival, and survival of adult sea otters at Kodiak Island, Alaska. Can J Zool 73:1161-1169

Monson DH, Doak DF, Ballachey BE, Johnson A, Bodkin JL (2000a) Long-term impacts of the Exxon Valdez oil spill on sea otters, assessed through age dependent mortality patterns. Proc Natl Acad Sci USA 97:6562-6567

Monson DH, Estes JA, Bodkin JL, Siniff DB (2000b) Life history plasticity and population regulation in sea otters. Oikos 90:457-468

O'Clair CE, Short JW, Rice SD (1996) Contamination of intertidal and subtidal sediments by oil from the Exxon Valdez in Prince William Sound. In: Rice SD, Spies RB, Wolfe DA, Wright BA (eds) Proc Exxon Valdez Oil Spill Symp. Am Fish Soc Symp 18:61-93

Ostfeld RS (1982) Foraging strategies and prey switching in California sea otter. Oecologia 53:170-178

Paine RT, Ruesink JL, Sun A, Soulanille EL, Wonham MJ, Harley CDG, Brumbaugh DR, Secord DL (1996) Trouble on oiled waters: lessons from the Exxon Valdez oil spill. Annu Rev Ecol Syst 27:197-235

Peterson CH (2001) The Exxon Valdez oil spill in Alaska: acute, indirect and chronic effects on the ecosystem. Adv Mar Biol 39:1-103

Reidman ML, Estes JA (1990) The sea otter (Enhydra lutris): behavior, ecology and natural history. US Fish Wild Serv Biol Rep 90(14)

Editorial responsibility: Charles Peterson (Contributing Editor), Morehead City, North Carolina, USA
Simenstad CA, Estes JA, Kenyon KW (1978) Aleuts, sea otters, and alternate stable-state communities. Science 200:403-411

Sinclair ARE (1977) The African buffalo. University of Chicago Press, Chicago

Sinclair ARE, Dublin EH, Borner M (1985) Population regulation of Serengeti wildebeest: a test of the food hypothesis. Oecologia 65:266-268

Skogland T (1983) The effects of density dependent resource limitation on size of wild reindeer. Oecologia 60: $156-168$

Skogland T (1985) The effects of density dependent resources limitation on the demography of the wild reindeer. J Anim Ecol 54:359-374

Snedecor GW, Cochran WG (1969) Statistical Methods. Iowa State University Press, Ames

Spies RB, Rice SD, Wolfe DA, Wright BA (1996) The effects of the Exxon Valdez oil spill on the Alaskan coastal environment. In: Rice SD, Spies RB, Wolfe DA, Wright BA (eds) Proc Exxon Valdez Oil Spill Symp. Am Fish Soc Symp 18:1-16

Stewart-Oaten A, Murdoch WW, Parker KP (1986) Environmental impact assessment: 'pseudoreplication' in time? Ecology 67:929-940

Trowbridge C, Baker TT, Johnson JD (1998) Effects of hydrocarbons on bivalves following the Exxon Valdez oil spill: fish/shellfish study 13. Exxon Valdez Oil Spill Trustee Council, Anchorage, AK

VanBlaricom GR (1988) Effects of foraging by sea otters on mussel-dominated intertidal communities. In: VanBlaricom GR, Estes JA (eds) The community ecology of sea otters. Springer-Verlag, Berlin, p 48-91

Virgil JA, Messier F (1997) Habitat suitability in muskrats: a test of the food limitation hypothesis. J Zool 243: 237-253

Wacasey JW, Atkinson EG (1987) Energy values of marine benthic invertebrates from the Canadian Arctic. Mar Ecol Prog Ser 39:243-250

Wolfe DA, Hameedi M, Galt JA, Watabayashi G and 8 others (1994) The fate of the oil spilled from the Exxon Valdez. Environ Sci Technol 28:561-568

Submitted: April 14, 2000; Accepted: April 26, 2002

Proofs received from author(s): September 10, 2002 